\title{
In planta expression of a protein encoded by the extrachromosomal DNA of a phytoplasma and related to geminivirus replication proteins
}

\author{
Hisashi Nishigawa, ${ }^{1}$ Shin-ichi Miyata, ${ }^{1}$ Kenro Oshima, ${ }^{1}$ Toshimi \\ Sawayanagi, ${ }^{1}$ Akihiro Komoto, ${ }^{1}$ Tsutomu Kuboyama, ${ }^{2}$ Izumi Matsuda, ${ }^{3}$ \\ Tsuneo Tsuchizaki ${ }^{4}$ and Shigetou Namba ${ }^{1}$
}

Author for correspondence: Shigetou Namba. Tel: +81424 69 3125. Fax: + 81424698786.

e-mail:snamba@ims.u-tokyo.ac.jp

\footnotetext{
1 Laboratory of Bioresource Technology, Graduate School of Frontier Sciences, The University of Tokyo, 1-1-1 Yayoi, Bunkyo-ku, Tokyo 113-8657, Japan

2 Laboratory of Plant Breeding and Genetics, Graduate School of Agricultural and Life Sciences, The University of Tokyo, 1-1-1 Yayoi, Bunkyo-ku, Tokyo 113-8657, Japan

3 National Agricultural Research Center, 3-1-1 Kannondai, Tsukuba, Ibaraki 305-8666, Japan

4 Koibuchi College of Agriculture, 5965 Koibuchi, Uchihara-cho, Higashi-ibaraki, Ibaraki 319-0323, Japan
}

\begin{abstract}
A new extrachromosomal DNA, EcOYW1, was cloned from the onion yellows phytoplasma (OY-W). Southern blot and PCR analysis showed that EcOYW1 is not present in the OY-M, a mild symptom line derived from $O Y-W$. We determined the complete nucleotide sequence of EcOYW1; it is a circular dsDNA of 7.0 kbp in length, which contains seven ORFs. ORF1 encoded a homologue of the geminivirus Rep protein. Western immunoblot analysis revealed that this Rep homologue is expressed in OY-W infected plants, suggesting that EcOYW1 replicates via a geminivirus-like rolling-circle replication mechanism. EcOYW1 is the first phytoplasmal extrachromosomal DNA shown to express encoded genes.
\end{abstract}

Keywords: phytoplasma, extrachromosomal DNA, Rep protein, geminivirus

\section{INTRODUCTION}

Plant pathogenic phytoplasmas are prokaryotic organisms that have no cell wall and are associated with numerous plant diseases (Kirkpatrick, 1992; McCoy et al., 1989). Due to the difficulty in culturing phytoplasmas in vitro, these organisms remain one of the most poorly characterized groups of plant pathogens. Onion yellows phytoplasma (OY), belonging to aster yellows (AY)clade phytoplasmas, is the causal agent of onion yellows disease, which produces a wide variety of symptoms in its plant hosts, including virescence (excessive greening of floral tissue), yellowing, phyllody (leaf-like petals and sepals), stunting, proliferation and witches' broom (Shiomi et al., 1996). A wild-type line of onion yellows phytoplasma (OY-W) was isolated in Saga Prefecture,

Abbreviations: $\mathrm{AY}$, aster yellows; OY, onion yellows; OY-M, mild symptom line of onion yellows; OY-W, wild-type onion yellows phytoplasma; SCWL, sugar cane white leaf; TGMV, tomato golden mosaic virus; VAC, Vaccinium witches' broom.

The GenBank accession number for EcOYW1 is AB010426.
Japan in May 1982 (Shiomi et al., 1996). We previously reported a mild-symptom line (OY-M) that induces milder symptoms than OY-W on the host plant garland chrysanthemum (Chrysanthemum coronarium) (Shiomi et al., 1998; Kuboyama et al., 1998). OY-M was isolated from OY-W maintained in the garland chrysanthemum in a greenhouse using the insect vector Macrosteles striifrons Anufriew.

Extrachromosomal DNA, including ss- and dsDNA, associated with some spiroplasmas, mycoplasmas and acholeplasmas, has been described (Maniloff, 1988; Razin, 1985; Renaudin \& Bove, 1994). Extrachromosomal DNA was also found in phytoplasmas (Davis et al., 1988; Sears et al., 1989; Bertaccini et al., 1990; Harrison et al., 1991; Goodwin et al., 1994). The nucleotide sequences of some extrachromosomal DNA from the AY group of phytoplasmas (partial sequence; approx. $200 \mathrm{bp}$ ), Vaccinium witches' broom (VAC) phytoplasma (approx. $1.5 \mathrm{kbp}$ ) and sugarcane white leaf (SCWL) phytoplasma (approx. $2.7 \mathrm{kbp}$ ) have been reported (Rekab et al., 1999; Kuske \& Kirkpatrick, 1990; Nakashima \& Hayashi, 1997). Previously, we 
reported a $3.6 \mathrm{kbp}$ DNA fragment of the dsDNA, pOYW1, from OY-W phytoplasma and suggested that pOYW1 is a plasmid replicating by a rolling-circle replication mechanism (Kuboyama et al., 1998).

In other plant-pathogenic bacteria, it is well known that plasmid-encoded genes play important roles in the pathogenicity and virulence (Panopoulos \& Peet, 1985). We previously reported that the copy number of pOYW1 was higher in OY-W phytoplasma than OY-M and suggested that this difference might have some relationship to the differences in pathogenicity. However, nucleotide sequence information on pOYW1 alone is not sufficient to deduce its biological significance in the pathogenicity of phytoplasmas.

In this paper, we report another extrachromosomal DNA from OY-W. This replicon was revealed to encode a homologue of geminivirus replication protein Rep; it was not found in OY-M, suggesting that it might also be related to the pathogenicity of OY-W.

\section{METHODS}

Phytoplasmas and phytoplasma-infected plants. OY-W and OY-M were used for these experiments. Healthy garland chrysanthemum plants were infected with OY-W or OY-M using the insect vector $M$. striifrons as described previously (Shiomi et al., 1998; Kuboyama et al., 1998).

Extraction of DNA from infected plants. The phytoplasmaenriched fraction of infected garland chrysanthemums was prepared as reported previously (Lee \& Davis, 1983). Total DNA was extracted from this fraction following the method of a previous report (Kuboyama et al., 1998).

Cloning and sequencing the extrachromosomal DNA. The total DNA of the phytoplasma-enriched fraction of infected garland chrysanthemum plants was electrophoresed and stained with ethidium bromide. As shown in Fig. 1, several

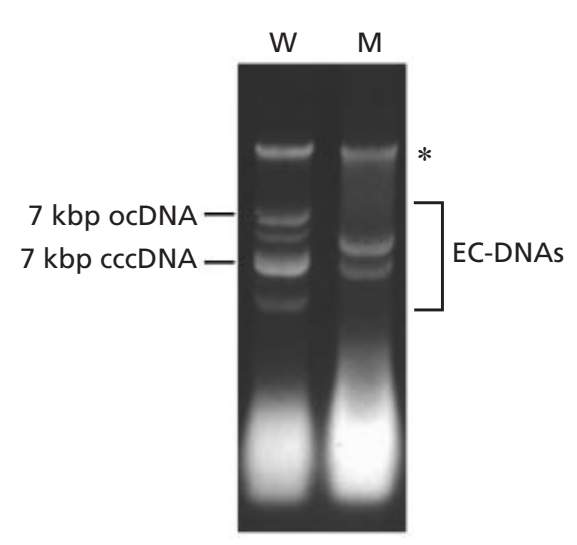

Fig. 1. Agarose gel electrophoresis of the phytoplasmaenriched total DNA extracted from plants infected with OY-W and OY-M. The extrachromosomal DNA regions are indicated as EC-DNAs. An asterisk indicates the phytoplasma chromosomal DNA band. $7 \mathrm{kbp}$ ocDNA and $7 \mathrm{kbp}$ cccDNA indicate the migration distances of $7 \mathrm{kbp}$ open- and closed-circular DNA size markers, respectively, electrophoresed under the same conditions. W, OY-W; M, OY-M.
DNA bands were observed from OY-W and OY-M DNA. In addition to the chromosomal DNA band (indicated by an asterisk), at least four major extrachromosomal DNA bands were observed in lane W, whilst only two bands were observed in lane $M$.

The largest extrachromosomal DNA band observed in OY-W DNA (lane W), close to a $7 \cdot 0 \mathrm{kbp}$ open circular DNA size marker, was extracted from agarose gel, digested with EcoR V and cloned into the SmaI site of pUC18. A clone containing a $2.5 \mathrm{kbp}$ insert ( $\mathrm{p} 2.5$ ) was sequenced by the dideoxynucleotide chain termination method with an automatic DNA sequencer (Applied Biosystems 377; Perkin Elmer). Sequence analysis was performed with the BLAST algorithm (Altschul et al., 1990) available through the NCBI server (National Center for Biotechnology Information). The ORFs that encode over 100 aa were used for BLASTP searches of all non-redundant peptide databases (GenBank CDS translations + PDB + SWISSPROT + PIR + PRF).

To obtain the remaining part of the possibly circular extrachromosomal DNA, we utilized the sequence information of $\mathrm{p} 2.5$ to design inverse PCR primers in outward orientations. A pair of inverse PCR primers, P1 (5' $5^{\prime}$ TCT CTT TCT TGT CAA AGC CCC TA- $\left.3^{\prime}\right)$ and P2 (5'-TCT TCG GGT TCT TGT TTT TCA GTT-3'), and OY-W DNA as a template, were used for inverse PCR. Amplification was performed in a thermal cycler (Perkin Elmer 9700) for 30 cycles, under the following conditions: denaturation for $15 \mathrm{~s}$ at $94^{\circ} \mathrm{C}$, annealing for $30 \mathrm{~s}$ at $55^{\circ} \mathrm{C}$, and extension for $3 \mathrm{~min}$ at $60^{\circ} \mathrm{C}$. The amplified $4.5 \mathrm{kbp}$ fragment was cloned (p4.5) and sequenced. Complete sequencing of p2.5 and p4.5 suggested that the original DNA was a circular 7.0 kbp DNA possessing a single HindIII restriction site. Subsequently, from a shotgun library of HindIII-digested total DNA of an OY-W phytoplasma-enriched fraction, a single $7 \cdot 0 \mathrm{kbp}$ clone $(\mathrm{p} 7.0)$, which hybridized to both $\mathrm{p} 2.5$ and $\mathrm{p} 4.5$, was obtained. Sequence analysis of p7.0 was performed as described above.

PCR amplification to detect the circular extrachromosomal DNA. To detect EcOYW1 from OY-W or OY-M infected plants, each PCR primer set for the $2.5 \mathrm{kbp}$ or the $4.5 \mathrm{kbp}$ DNA fragment of EcOYW1 was used. The primers P1 and P2 were used for the $4.5 \mathrm{kbp}$ DNA fragment amplification. The primers P3 (5'-AAC CCT GAA ATC TCA TTT GA-3') and P4 (5'-AAC TTT AAC CAC AGG TGC A-3') were synthesized and used to amplify the $2.5 \mathrm{kbp}$ DNA fragment.

Southern blot hybridization. Total DNA extracted from phytoplasma-enriched fractions of OY-W and OY-M infected plants was digested with restriction endonucleases, and Southern hybridization analysis was performed. Transblotting was done using the method described by Sambrook et al. (1989). Detection was done with a digoxigenin-labelled probe and a DIG DNA labelling and detection kit (Roche Diagnostics) following the manufacturer's guidelines. Fragments of $306 \mathrm{bp}$ and $354 \mathrm{bp}$, corresponding to nt 5033-5338 (probe A, Fig. 2) and 6583-6936 (probe B, Fig. 2), respectively, of EcOYW1 were used as probes.

Preparation of anti-ORF1 protein serum. The ORF1 coding region (1041 bp) was amplified by PCR with primers Rep-N (5'-AGAATTCCATAT GAA AAA AAC AAA TAA AGT TAA AAA AGA-3') and Rep-C (5' GTG GTT TAT ATT TCA TAT TGA-3'), carrying restriction enzyme sites at their $5^{\prime}$ ends (underlined). This PCR product was digested with EcoRI and $\mathrm{XhoI}$, and inserted into pGEX-4T-1 vector plasmid (Amersham Pharmacia Biotech). The $2 \cdot 1 \mathrm{kbp} P v u \mathrm{II}-\mathrm{XhoI}$ fragment of this plasmid was ligated 


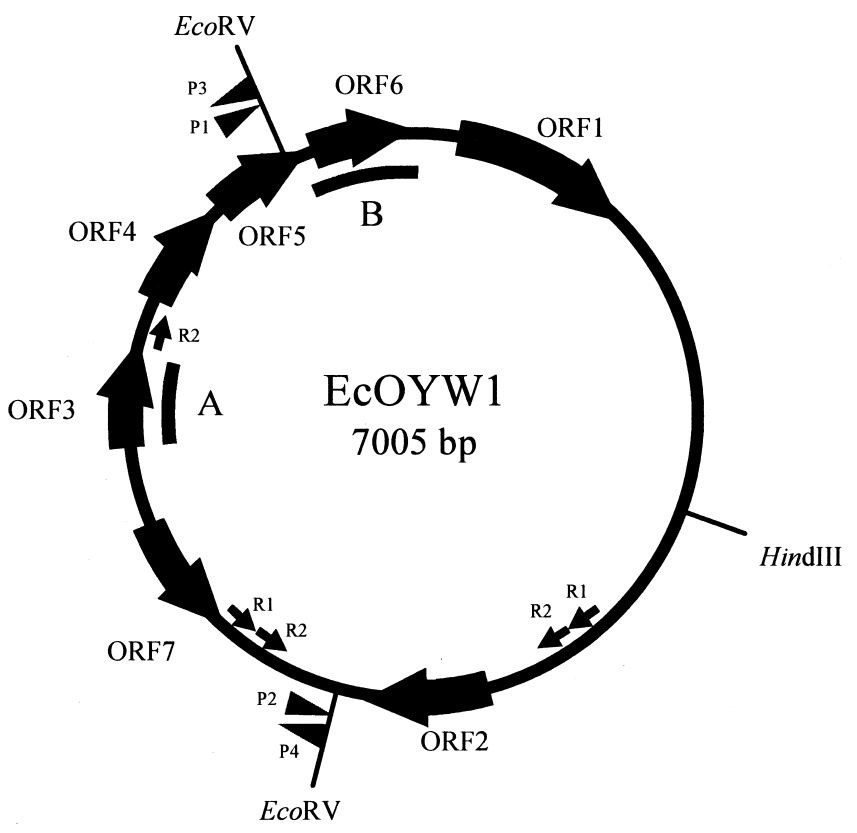

Fig. 2. Schematic physical map of EcOYW1. EcoRV and HindIII cleavage sites are indicated. Putative ORFs are shown on the circle as thick arrows. The repeat sequences R1 and R2 are shown inside the circle as small arrows. A and B denote the regions used as the probe for the Southern blot hybridization shown in Fig. 3(b). Arrowheads P1-P4 indicate the positions and orientations of the PCR primers.

into the $S p h I-X h o I$ site of pET30a vector (Novagen), of which $S p h I$ site had been filled-in with Klenow. The resulting plasmid encodes a (glutathione $S$-transferase)-(Rep) $-(6 \times$ histidinetag) fusion protein, which was expressed in Escherichia coli BL21 after IPTG induction and purified with a His-Bind resin column following the manufacturer's guidelines (Novagen). A rabbit was immunized with the purified protein and antiserum was obtained. IgG was purified from the anti-ORF1 protein antiserum using a Protein A column (Bio-Rad).

SDS-PAGE and Western blot analysis. Total protein was extracted from healthy and OY-W infected garland chrysanthemum plants. The phytoplasma-enriched fraction, prepared as described above, was suspended in $1 \mathrm{ml}$ sonication buffer $(20 \mathrm{mM}$ Tris/HCl, pH 7.5, $150 \mathrm{mM} \mathrm{NaCl}, 1 \mathrm{mM}$ EDTA, 1 mM PMSF, 1 mM 2-mercaptoethanol) (Sambrook et al., 1989) and sonicated for $5 \mathrm{~min}$, before separation into soluble and insoluble fractions by centrifugation $(20000 \mathrm{~g}$, $15 \mathrm{~min}$ ); the insoluble fraction was suspended in $1 \mathrm{ml}$ sonication buffer. These samples were electrophoresed into SDSPAGE gels and analysed using Western immunoblotting (Sambrook et al., 1989).

The fractionated proteins were transferred onto PVDF membranes. These membranes were first reacted with rabbit antiORF1 protein IgG, and then with a mouse anti-rabbit Ig conjugated with alkaline phosphatase. Signals were detected using the ECF Western Blotting Reagent Pack (Amersham Pharmacia Biotech) and a Fluoro Imager (Molecular Dynamics). Pre-immune IgG was used as a control. Prestained SDS-PAGE Standards (Bio-Rad) were used as molecular mass markers.

\section{RESULTS}

\section{Cloning the extrachromosomal DNA}

We cloned the largest extrachromosomal DNA band from the OY-W enriched fraction (Fig. 1, lane W). Clones p2.5 and p7.0, isolated from the EcoRV- and HindIII-fragment DNA libraries, respectively, and a clone p4.5, amplified by inverse PCR using p2.5 sequence information, were all sequenced. The nucleotide sequence of the extrachromosomal DNA deduced from the slightly overlapping $\mathrm{p} 2.5$ and $\mathrm{p} 4.5$ clones and that from p7.0 were revealed to be identical. We concluded that these clones are derived from the same
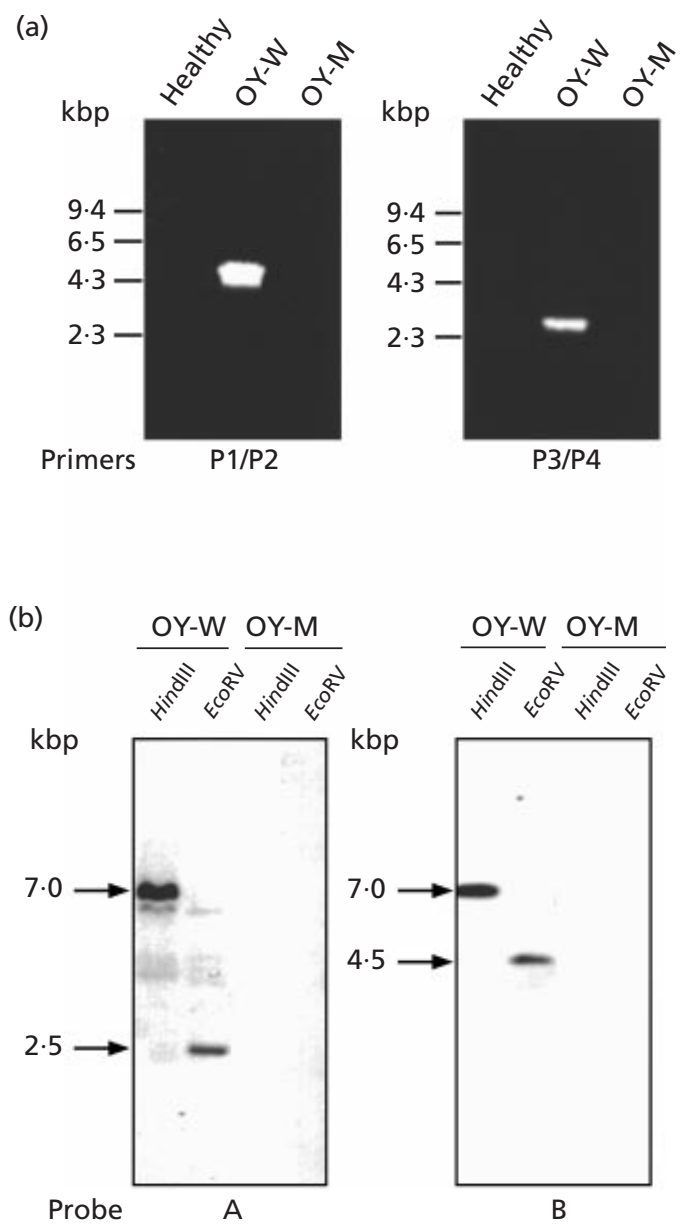

Fig. 3. (a) PCR amplification of a part of EcOYW1. Amplified DNA was electrophoresed in an agarose gel and stained with ethidium bromide. The template DNA is indicated above each lane: Healthy, total DNA extracted from healthy garland chrysanthemum; OY-W and OY-M, total DNA from the phytoplasma-enriched fraction of OY-W- and OY-M-infected plants, respectively. P1-P4 are the primers used for PCR indicated in Fig. 2. (b) Southern blot hybridization of the total DNA from the phytoplasma-enriched fraction of plants infected with OY-W or OY-M. The labels on the lanes indicate which restriction enzyme was used. Probes $A$ and $B$ are EcOYW1 fragments labelled as regions $A$ and $B$ in Fig. 2, respectively. The estimated size of DNA fragments is shown. 
Table 1. Summary of the ORFs in EcOYW1

NS, No similarity to any functional protein in the databases.

\begin{tabular}{|crcc|}
\hline ORF & Position & $\begin{array}{c}\text { Peptide size } \\
\text { (aa) }\end{array}$ & Putative function \\
\hline ORF1 & $83-1126$ & 347 & Replication \\
ORF2 & $3214-3660$ & 148 & NS \\
ORF3 & $5033-5360$ & 109 & NS \\
ORF4 & $5510-6070$ & 186 & Copy number control \\
ORF5 & $6073-6519$ & 148 & NS \\
ORF6 & $6541-6930$ & 129 & NS \\
ORF7 & $4749-4348$ & 133 & \\
\hline
\end{tabular}

extrachromosomal DNA and named it EcOYW1 (extrachromosomal DNA 1 of OY-W). EcOYW1, a circular DNA of length 7005 bp (GenBank no. AB010426), is shown schematically in Fig. 2. The $\mathrm{G}+\mathrm{C}$ content of the nucleotide sequence of EcOYW1 is $21.9 \mathrm{~mol} \%$.

\section{EcOYW1 was not found in OY-M}

EcOYW1 was cloned from OY-W DNA. DNA extracted from OY-M (Fig. 1, lane M) suggested the absence of this molecule in OY-M. Therefore, the presence of EcOYW1 was examined by PCR using two primer sets specific for p4.5 and p2.5. As shown in Fig. 3(a), neither a $4.5 \mathrm{kbp}$ nor a $2.5 \mathrm{kbp}$ fragment was amplified from healthy plant DNA or OY-M infected plant DNA extracted from the phytoplasma-enriched fraction. Southern blot hybridization was then performed against total DNA of the phytoplasma-enriched fraction using 306 bp and 354 bp DNA fragments of EcOYW1 (regions $A$ and $B$ in Fig. 2) as probes that specifically hybridize $2.5 \mathrm{kbp}$ and $4.5 \mathrm{kbp}$ fragments, respectively. As shown in Fig. 3(b), when OY-W DNA was used, a $7.0 \mathrm{kbp}$ HindIII fragment was detected with both probes, and $2.5 \mathrm{kbp}$ and $4.5 \mathrm{kbp}$ EcoRV fragments were detected with $2.5 \mathrm{kbp}$ - and $4.5 \mathrm{kbp}$-fragment-specific probes, respectively. However, when OY-M DNA was used, no signal was detected. These data suggest that EcOYW1 does not exist in OY-M infected tissues.

\section{EcOYW1 encodes a homologue of geminivirus replication protein Rep}

We found seven ORFs in the complete nucleotide sequence of EcOYW1 (Fig. 2, Table 1). A search for similar sequences using BLAST showed that the deduced protein encoded by ORF1 shares a high level of similarity with Rep protein, a multifunctional replication protein found in plant viruses belonging to the family Geminiviridae. An overall similarity between a protein encoded by ORF1 and a Rep protein of Tomato golden mosaic virus (TGMV), a geminivirus, is $66 \%$. Homologous deduced proteins were also reported for the extrachromosomal DNA from SCWL and VAC phytoplasmas (Rekab et al., 1999; Nakashima \& Hayashi, 1997). Some of these proteins are aligned in Fig. 4. It was reported that motifs $1-3$ and helices 1 and 2 in the N-terminal domain of the Rep protein of TGMV were very important for replication of geminivirus genomic DNA (Orozco \& Hanley-Bowdoin, 1998). These domains were highly conserved in ORF1 of EcOYW1. Specifically, motifs 1 and 3 showed higher similarities of $80 \%$ and $83 \%$, respectively. The Tyr residue in motif 3 (indicated by an arrowhead in Fig. 4), which is considered necessary for DNA cleavage, was conserved. In addition, the nucleotide-binding site called the P-loop in the C-terminal domain was also highly conserved with $100 \%$ similarity. Therefore, we suggest that the protein encoded by ORF1 functions as a replication-initiation protein.

\section{The Rep homologue encoded by ORF1 is expressed in a phytoplasma-infected plant}

To see if ORF1 is expressed in planta, we performed a Western immunoblot analysis. As shown in Fig. 5, the anti-ORF1 protein IgG specifically reacted with a $42 \mathrm{kDa}$ protein, which has a molecular mass consistent with the putative ORF1 protein, in the OY-W lane. This suggests that the Rep homologue encoded by ORF1 of EcOYW1 is expressed in plant cells infected by the phytoplasma. This is the first time that the expression of a functional protein encoded by the extrachromosomal DNA of a phytoplasma has been detected.

\section{Other interesting features of the EcOYW1 structure}

The deduced protein encoded by ORF4 shares a high level of similarity to cop, the plasmid copy number control gene of pIP404, a bacteriocinogenic plasmid of Clostridium perfringens (Fig. 6) (Garnier \& Cole, 1988). Studies of C. perfringens have shown that the cop gene functions as a negative regulator of copy number. It is interesting that EcOYW1 encodes two proteins showing similarity to Rep and Cop proteins, which are presently recognized as being part of two different replication regulatory systems. None of the remaining ORFs showed significant similarity to any known proteins.

Similar to the VAC phytoplasma extrachromosomal DNA (Rekab et al., 1999), EcOYW1 contains some 


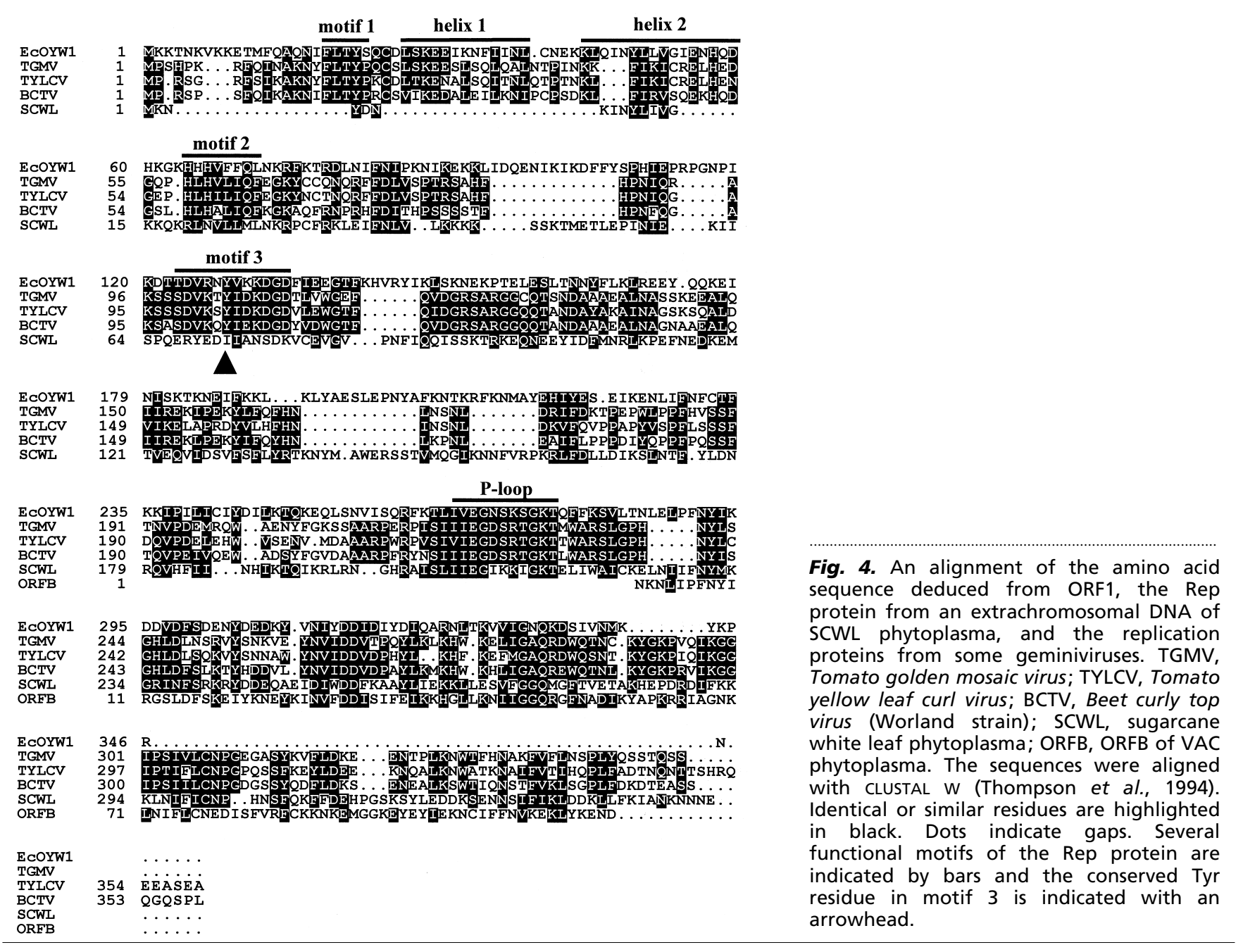

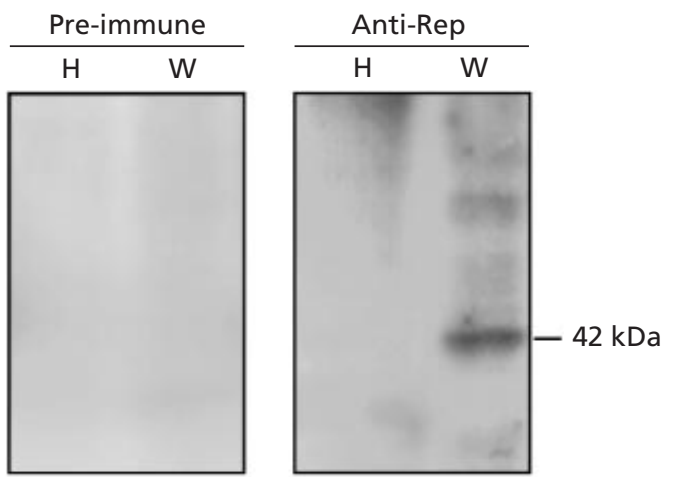

Fig. 5. Western immunoblot analysis. The sonicated soluble fraction of total phytoplasma-enriched protein was used. Lanes: $\mathrm{H}$, healthy plant total protein (prepared by the same method as OY-W); W, OY-W infected plant. Each membrane was first reacted with pre-immune IgG or anti-ORF protein IgG.

putative prokaryotic ( -35 signal) and eukaryotic (TATA box) promoter-like signals upstream from ORF1. Furthermore, two previously unreported, long repeated sequences are found in EcOYW1 (indicated with small arrows in Fig. 2). A 111 bp sequence (R1) is repeated twice and a 109 bp sequence (R2) is repeated three times. Interestingly, two copies of $\mathrm{R} 1$ and $\mathrm{R} 2$ are located adjacent to each other, as though R1-R2 is a long inverted repeat in EcOYW1.

\section{DISCUSSION}

We characterized EcOYW1, a novel phytoplasma extrachromosomal DNA, which is the largest extrachromosomal DNA reported in phytoplasmas. Previous studies of phytoplasma extrachromosomal DNA might easily have confused the replicative forms of mollicute viruses or co-infected plant DNA viruses with the extrachromosomal DNA (Renaudin \& Bove, 1994; Nur et al., 1987). EcOYW1 is definitely a phytoplasma extrachromosomal DNA for several reasons. First, the results of Southern hybridization and electrophoresis were reproducible. Therefore, the OY-W-specific DNA fraction was not the product of contamination. Second, electron microscopic observations did not observe any virus particles (data not shown). Third, although the amino acid sequence of ORF1 shares a high level of similarity with that of 


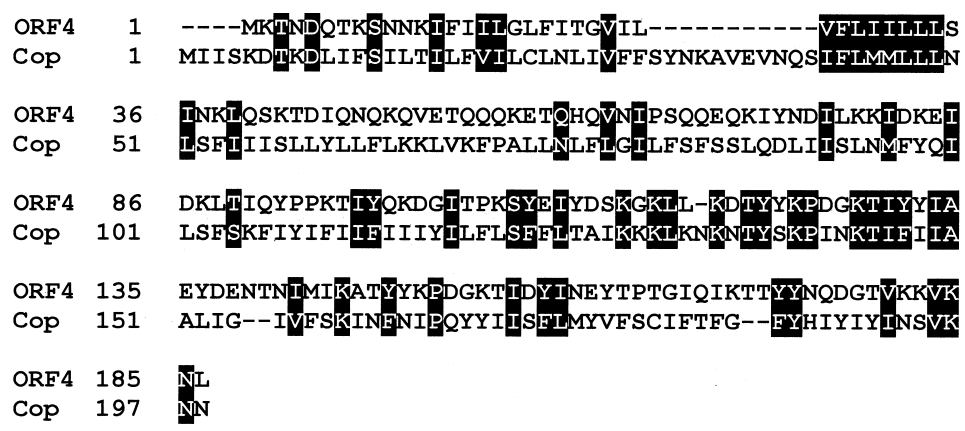

Fig. 6. An alignment of the amino acid sequence deduced from ORF4 and the Cop protein from plP404 plasmid of C. perfringens. The sequences were aligned the same as Fig. 4.

geminiviral Rep and has conserved amino acid motifs, the nucleotide similarity is only $26 \%$. Finally, ORF4 is homologous to the cop gene of plasmid pIP404 in C. perfringens, which is closely taxonomically related to phytoplasma (Gundersen et al., 1994). We feel that these facts confirm that EcOYW1 is a phytoplasma extrachromosomal DNA. The $\mathrm{G}+\mathrm{C}$ content of the nucleotide sequence of EcOYW1 was $21.9 \mathrm{~mol} \%$. An extrachromosomal DNA found in SCWL phytoplasma (Nakashima \& Hayashi, 1997) and a plasmid, pOYW1, found in OY phytoplasma (Kuboyama et al., 1998) were also reported to be extremely AT-rich.

Rekab et al. (1999) reported geminivirus-related extrachromosomal DNA from an X-clade phytoplasma. Although they only reported a partial sequence, their ORFB was highly homologous to the C-terminal region of geminivirus replication proteins. Our results imply that both X-clade and AY-clade phytoplasmas (containing OY-W) possess extrachromosomal DNA, which encodes a Rep gene homologue. Furthermore, we confirmed the expression of this Rep homologue protein. This suggests that ORFB of the X-clade-specific extrachromosomal DNA might also be expressed.

It has been suggested that the geminiviruses originated from a prokaryotic plasmid containing the rolling circle DNA replication initiation protein (Koonin \& Ilyina, 1992). In addition, the Nicotiana tabacum nuclear genome was reported to carry multiple direct repeats of a geminivirus-related DNA containing the Rep gene region of TGMV (Kenton et al., 1995). These sequences are thought to have arisen during the evolution of Nicotiana, from illegitimate recombination following geminivirus infection. Therefore, it appears that Rep homologous sequences have been widely distributed in viruses, mollicutes and plants during evolution. Further experiments are now in progress using antibodies against Rep to clarify whether an ORF1 protein exists both in phytoplasma-infected plants and in insects.

We previously reported that the copy number of a plasmid pOYW1 from OY-W was $4 \cdot 2$ times greater than that from OY-M (Kuboyama et al., 1998). In addition, here we showed that EcOYW1 was not found in OY-M. Thus, our results confirm differences in the extrachromosomal DNA between OY-W and OY-M. However, the relationship between the milder symptoms of OY-M and the absence of the EcOYW1 is still unknown. It could be possible that the EcOYW1 ORFs with no similarity to any known function encode unknown pathogenicity genes. Further investigation of the extrachromosomal DNA should enable the elucidation of the mechanism for these intriguing differences in symptoms, and the pathogenicity of phytoplasmas.

\section{ACKNOWLEDGEMENTS}

We thank Mr Shigeru Hatano for his excellent technical assistance. This work was supported partly by grants-in-aid from the Ministry of Education, Science and Culture of Japan (09460155), and by the programme for Promotion of Basic Research Activities for Innovative Biosciences (PROBRAIN), of the Ministry of Agriculture, Forestry and Fisheries of Japan.

\section{REFERENCES}

Altschul, S. F., Gish, W., Miller, W., Myers, E. W. \& Lipman, D. J. (1990). Basic local alignment search tool. J Mol Biol 215, 403-410.

Bertaccini, A., Davis, R. E., Lee, I.-M., Conti, M., Dally, E. L. \& Douglas, S. M. (1990). Detection of chrysanthemum yellows mycoplasmalike organism by dot hybridization and Southern blot analysis. Plant Dis 74, 40-43.

Davis, M. J., Tsai, J. H., Cox, R. L., McDaniel, L. L. \& Harrison, N. A. (1988). Cloning of chromosomal and extrachromosomal DNA of the mycoplasmalike organism that causes maize bushy stunt disease. Mol Plant-Microbe Interact 4, 295-302.

Garnier, T. \& Cole, S. T. (1988). Identification and molecular genetic analysis of replication functions of the bacteriocinogenic plasmid pIP404 from Clostridium perfringens. Plasmid 19, 151-160.

Goodwin, P. H., Xue, B. G., Kuske, C. R. \& Sears, M. K. (1994). Amplification of plasmid DNA to detect plant pathogenic mycoplasmalike organism. Ann Appl Biol 124, 27-36.

Gundersen, D. E., Lee, I.-M., Rehner, S. A., Davis, R. E. \& Kingsbury, D. T. (1994). Phylogeny of mycoplasmalike organisms (phytoplasmas), a basis for their classification. J Bacteriol 176, 5244-5254.

Harrison, N. A., Tsai, J. H., Bourne, C. M. \& Richardson, P. A. (1991). Molecular cloning and detection of chromosomal and extrachromosomal DNA of mycoplasmalike organisms associated with witches' broom disease of pigeon pea in Florida. Mol Plant-Microbe Interact 4, 300-307.

Kenton, A., Khashoggi, A., Parokonny, A., Bennett, M. D. \& Lichtenstein, C. (1995). Chromosomal location of endogenous geminivirus-related DNA sequences in Nicotiana tabacum L. Chromosome Res 3, 346-350. 
Kirkpatrick, B. C. (1992). Mycoplasma-like organisms: plant and invertebrate pathogens. In The Prokaryotes, 2nd edn, pp. 4050-4067. Edited by A. Balows, H. G. Truper, M. Dworkin, W. Harder \& K. H. Schleifer. New York: Springer.

Koonin, E. V. \& Ilyina, T. V. (1992). Geminivirus replication proteins are related to prokaryotic plasmid rolling circle DNA replication initiator proteins. J Gen Virol 73, 2763-2766.

Kuboyama, T., Huang, C.-C., Lu, X., Sawayanagi, T., Kanazawa, T., Kagami, T., Matsuda, I., Tsuchizaki, T. \& Namba, S. (1998). A plasmid isolated from phytopathogenic onion yellows phytoplasma and its heterogeneity in the pathogenic phytoplasma mutant. Mol Plant-Microbe Interact 11, 1031-1037.

Kuske, C. R. \& Kirkpatrick, B. C. (1990). Identification and characterization of plasmids from the western aster yellows mycoplasmalike organism. J Bacteriol 172, 1628-1633.

Lee, I.-M. \& Davis, R. E. (1983). Phloem-limited prokaryotes in sieve elements isolated by enzyme treatment of diseased plant tissues. Phytopathology 73, 1540-1543.

McCoy, R. E., Caudwell, A., Chang, C. J. \& 15 other authors (1989). Plant disease associated with mycoplasma-like organisms. In The Mycoplasmas, vol. 5, pp. 546-640. Edited by R. F. Whitcomb \& J. G. Tully. New York: Academic Press.

Maniloff, J. (1988). Mycoplasma viruses. Crit Rev Microbiol 15, 339-389.

Nakashima, K. \& Hayashi, T. (1997). Sequence analysis of extrachromosomal DNA of sugarcane white leaf phytoplasma. Ann Phytopathol Soc Jpn 63, 21-25.

Nur, I., Leblanc, D. J. \& Tully, J. G. (1987). Short, interspersed, and repetitive DNA sequences in Spiroplasma species. Plasmid 17, 110-116.

Orozco, B. M. \& Hanley-Bowdoin, L. (1998). Conserved sequence and structural motifs contribute to the DNA binding and cleavage activities of a geminivirus replication protein. J Biol Chem 273, 24448-24456.
Panopoulos, N. \& Peet, R. C. (1985). The molecular genetics of plant pathogenic bacteria and their plasmids. Annu Rev Phytopathol 23, 381-419.

Razin, S. (1985). Molecular biology and genetics of mycoplasmas (Mollicutes). Microbiol Rev 49, 419-455.

Rekab, D., Carraro, L., Schneider, B., Seemüller, E., Chen, J., Chang, C. J., Locci, R. \& Firrao, G. (1999). Geminivirus-related extrachromosomal DNAs of the X-clade phytoplasmas share high sequence similarity. Microbiology 145, 1453-1459.

Renaudin, J. \& Bove, J. M. (1994). SpV1 and SpV4, spiroplasma viruses with circular, single-stranded DNA genomes, and their contribution to the molecular biology of spiroplasmas. Adv Virus Res 44, 429-463.

Sambrook, J., Fritsch, E. F. \& Maniatis, T. (1989). Molecular Cloning: a Laboratory Manual, 2nd edn. Cold Spring Harbor, NY: Cold Spring Harbor Laboratory.

Sears, B. B., Lim, P.-O., Holland, N., Kirkpatrick, B. C. \& Klomparens, K. L. (1989). Isolation and characterization of DNA from a mycoplasmalike organism. Mol Plant-Microbe Interact 2, 175-180.

Shiomi, T., Tanaka, M., Wakiya, H. \& Zenbayashi, R. (1996). Occurrence of welsh onion yellows. Ann Phytopathol Soc Jpn 62, 258-260.

Shiomi, T., Tanaka, M., Sawayanagi, T., Yamamoto, S., Tsuchizaki, T. \& Namba, S. (1998). A symptomatic mutant of onion yellows phytoplasma derived from a greenhouse-maintained isolate. Ann Phytopathol Soc Jpn 64, 501-505.

Thompson, J. D., Higgins, D. G. \& Gibson, T. J. (1994). CLUSTAL w : improving the sensitivity of progressive multiple sequence alignment through sequence weighting, position-specific gap penalties and weight matrix choice. Nucleic Acids Res 22, 4673-4680.

Received 13 June 2000; revised 4 October 2000; accepted 3 November 2000. 